\title{
Barite study constrains the origin of the Mountain Pass carbonatite REE deposit and links to alkaline magmatism, California, USA
}

\author{
K.E. WATTS * AND G.B. HAXEL ${ }^{2}$ \\ USGS, Moffett Field, CA 94035 USA, *kwatts@usgs.gov \\ USGS, Flagstaff, AZ 86001 USA
}

Although best known as a source of LREE, the Mountain Pass carbonatite also has extreme enrichment in $\mathrm{Ba}(10-20 \mathrm{wt} \% \mathrm{BaO})$ and a large proportion of barite phenocrysts, 5-30 vol\%. It is a carbonate-sulfate igneous rock. Barite is also common as a late-crystallizing accessory phase in shonkinite-syenite ultrapotassic silicate igneous rocks associated with the carbonatite. In these rocks barite is associated with primary phlogopite, clinopyroxene, Kfeldspar, titanite, apatite, and Fe-oxides. It forms inclusions, interstitial textures, and psuedomorphic replacement with these phases. Barite mineral chemistry for four samples of carbonatite (barite beforsite and barite dolosövite) and four alkaline igneous units (three shonkinite dikes and a syenite intrusion) was determined with a JEOL JXA-8230 SuperProbe electron microprobe at Stanford University, operated at $15 \mathrm{kV}, 30 \mathrm{nA}$, with a $2-5 \mu \mathrm{m}$ beam spot size. Barite crystals $(0.5-5 \mathrm{~cm})$ in the carbonatite have 59-66 wt $\% \mathrm{BaO}, 34-36 \mathrm{wt} \% \mathrm{SO}_{3}$, and $0.5-5 \mathrm{wt} \% \mathrm{SrO}$, with crosscutting veins and reaction rims of barite-celestine with 22$52 \mathrm{wt} \% \mathrm{BaO}, 36-41 \mathrm{wt} \% \mathrm{SO}_{3}$, and $11-37 \mathrm{wt} \% \mathrm{SrO}$. The celestine-rich rims are associated with bastnäsite, the LREE-fluorocarbonate ore mineral. For some grains, bastnäsite crystals form pseudomorphs along originally euhedral barite margins. Bastnäsite also forms cross-cutting veins in barite and other major phenocryst phases and $\mathrm{Sr}, \mathrm{F}$, and LREE are enriched in the carbonatite groundmass. Barite crystals $(50-100 \mu \mathrm{m})$ in the alkaline rocks have $62-$ $67 \mathrm{wt} \% \mathrm{BaO}, 33-36 \mathrm{wt} \% \mathrm{SO}_{3}$, and $0.5-4 \mathrm{wt} \% \mathrm{SrO}$; rims have generally higher $\mathrm{K}_{2} \mathrm{O}(\leq 0.15 \mathrm{wt} \%)$ and $\mathrm{SiO}_{2}(\leq 0.08$ $\mathrm{wt} \%)$, indicating igneous crystallization in evolving melts. These data support a genetic link between the carbonatite and ultrapotassic magmatic units, both of which crystallized igneous barite. Hydrothermal circulation of Sr- and LREErich fluids in the carbonatite led to alteration of barite rims to celestine and ore-grade bastnäsite mineralization. In-situ $\mathrm{Sr}$ isotope analyses of barite will be the focus of future work to assess crustal, mantle, and fluid sources in the genesis of the carbonatite ore body and associated alkaline rocks. 